\title{
Broad-scale association between seagrass cover and juvenile blue crab density in Chesapeake Bay
}

\author{
Gina M. Ralph*, Rochelle D. Seitz, Robert J. Orth, Kathleen E. Knick, \\ Romuald N. Lipcius
}

Virginia Institute of Marine Science, College of William and Mary, PO Box 1346, Gloucester Point, Virginia 23062, USA

\begin{abstract}
Although numerous small-scale laboratory, mesocosm, and field experiments have demonstrated that abundance, survival, and growth of juvenile fish and invertebrates are higher in vegetated than in unvegetated habitats, the effect of habitat quality (i.e. habitat complexity) within vegetated habitats has not been documented at a broad spatial scale. We examined the relationship between percent cover in seagrass beds (eelgrass Zostera marina, widgeon grass Ruppia maritima, and associated macroalgae) and juvenile blue crab Callinectes sapidus density at a broad spatial scale. We quantified the functional relationship between juvenile density and percent cover of vegetation by sampling in Chesapeake Bay (USA) seagrass beds utilized by juvenile blue crabs in the fall of 2007 and 2008, following peak postlarval blue crab recruitment. Based on Akaike's information criterion model comparisons, the most plausible model included both percent cover of vegetation and region of Chesapeake Bay. Juvenile crab density was a positive exponential function of percent cover of vegetation, and was augmented by 14 to $30 \%$, depending on year, for every $10 \%$ increase in cover. Density was approximately 2 times higher on the western shore of Chesapeake Bay than on the eastern shore. Seagrass bed area, presence or absence of algae, and distance to the mouth of the bay did not significantly influence density. An expected threshold (i.e. sigmoid) response of juvenile density to percent cover of vegetation was not evident, probably because this study was undertaken when recruitment was low, so habitats may not have been at carrying capacity. This study is the first to document the functional relationship between habitat quality and juvenile density at a broad spatial scale for a marine fish or invertebrate, and suggests that the quality of seagrass habitat influences population dynamics.
\end{abstract}

KEY WORDS: Recruitment · Nursery · Habitat quality · Akaike's information criterion · AIC model · Population dynamics

Resale or republication not permitted without written consent of the publisher

\section{INTRODUCTION}

The nursery role concept was introduced over a century ago to characterize the ecological function of near-shore shallow-water habitats, such as estuaries and lagoons, in species with complex life cycles that include ontogenetic shifts in habitat use. This early formulation offered the entire estuary as a nursery, but it was later suggested that specific habitats within the estuary were more important as nurseries than others (Beck et al. 2001). Typically, these were structurally complex habitats, such as mangroves, marshes, and seagrass meadows, which usually have higher densities of juvenile fish and invertebrates than adjacent unvegetated habitats (Heck et al. 2003, Minello et al. 2003). For example, a recent working group through the International Council for the Exploration of the Sea (ICES) examined the habitat utilization of all taxa for which ICES gives advice, as well as 12 invertebrate species (ICES 2012). All of the invertebrates and 17 , or $29 \%$, of the taxa examined utilize coastal habitats as nurseries. 
Vegetated habitats, particularly marsh and seagrass, have often been described as nurseries for blue crabs (e.g. Orth \& van Montfrans 1990), as most laboratory and field studies have found higher density, survival, or growth of young juveniles in seagrass habitats compared with nearby unvegetated habitats (see Lipcius et al. 2007 for a review). Near Ono Island, Alabama, juvenile blue crab abundance was higher in vegetated habitats than unvegetated habitats throughout most of the year (Williams et al. 1990). This pattern decreased with size, as the abundance of juveniles $>10 \mathrm{~mm}$ carapace width (CW) was not significantly different between the habitats (Williams et al. 1990). These patterns were also noted in a seagrass bed and an adjacent, unvegetated marsh creek in Chesapeake Bay (Orth \& van Montfrans 1987). At 2 locations near Galveston Island, Texas, the density of juvenile blue crabs $<40 \mathrm{~mm} \mathrm{CW}$ was higher in vegetated habitats, including seagrass and salt marsh, than in nearby unvegetated habitats (Thomas et al. 1990). Though there were no significant differences in juvenile density between vegetated and nearby unvegetated habitats at 2 locations in Great Bay, New Jersey, the low densities (0 to 3 crabs $\mathrm{m}^{-2}$ ) may have obscured any trends (Wilson et al. 1990). Juvenile density was also positively correlated with seagrass shoot density at Goodwin Islands, Virginia (Hovel \& Lipcius 2002).

Tethering experiments in Chesapeake Bay have indicated that survival of juvenile blue crabs is a function of both crab size and habitat (Pile et al. 1996, Schulman 1996, Lipcius et al. 2005, Hines 2007). Survival of juveniles 2 to $14 \mathrm{~mm} \mathrm{CW}$ was higher in seagrass than unvegetated habitats (Pile et al. 1996), whereas survival of larger juvenile crabs, i.e. 14 to $16 \mathrm{~mm} \mathrm{CW}$ (Pile et al. 1996) and 25 to $52 \mathrm{~mm} \mathrm{CW}$ (Lipcius et al. 2005), was similar in both habitats. In plots of artificial seagrass of varying shoot density, survival of juveniles was a function of size; survival of the smallest juveniles, ranging from 3 to $6 \mathrm{~mm} \mathrm{CW}$, was inversely related to shoot density, whereas survival of larger juveniles, 11 to $35 \mathrm{~mm} \mathrm{CW}$, was positively related to shoot density (Schulman 1996). Despite these numerous studies, few have addressed the role of habitat complexity within seagrass habitats (e.g. Hovel \& Lipcius 2001, 2002), and the findings of these studies may not apply to the entire population because of their small spatial scale (i.e. 1 to 2 field locations).

Seagrass beds in Chesapeake Bay have undergone severe fluctuations in the past $80 \mathrm{yr}$, with the most dramatic losses occurring in the 1930s following the wasting disease pandemic and in the 1970s following significant water-quality changes (Orth \& Moore 1983). Full recovery after the wasting disease was evident by the 1960s. Although recovery from the 1970s decline was observed through the 1990s, seagrass beds have once again been declining (Orth et al. 2010), prompting concerns that current declines could further compromise blue crab nurseries through reductions in the total seagrass bed extent and density. The area of individual seagrass beds and the presence of macroalgae, particularly the complex red macroalga Gracilaria spp., may also interact with the extent and density of seagrass beds to influence the density of juvenile blue crabs.

Given the absence of an evaluation of the relationship between features of seagrass habitats and juvenile blue crab density at a large spatial scale, we performed such an assessment across seagrass beds (and associated macroalgae) in Chesapeake Bay. The primary objective of this study was to quantify the relationship between the density of recently settled blue crabs and the percent cover of vegetation. We also evaluated the effects of environmental factors, including region of Chesapeake Bay (eastern or western shore), seagrass bed area, distance to the mouth of the bay, and presence or absence of macroalgae, on juvenile blue crab density.

\section{MATERIALS AND METHODS}

\section{Field surveys}

In 2007 and 2008, we used a stratified random sampling survey in seagrass beds throughout lower Chesapeake Bay in the fall (October and early November), as postlarval recruitment to the bay typically occurs from August to November (van Montfrans et al. 1990). Sampling sites were randomly generated, using an algorithm in ArcGIS, across shallow $(<2 \mathrm{~m})$ seagrass beds in lower Chesapeake Bay (Fig. 1), where primary blue crab settlement occurs (Van Engel 1958, Heck \& Thoman 1984, Lipcius et al. 2007), delineated from an annual aerial monitoring of all Chesapeake Bay underwater grass beds (for detailed methodology, see Orth et al. 2011). In the sampling, 2 species of seagrass were encountered, eelgrass Zostera marina and widgeon grass Ruppia maritima, which generally co-occur in many areas of the lower Chesapeake Bay (Orth \& Moore 1988).

The study was designed to be representative of the population; thus, samples were allocated based on the area of seagrass on both the eastern and western shores during the annual aerial seagrass monitoring, 


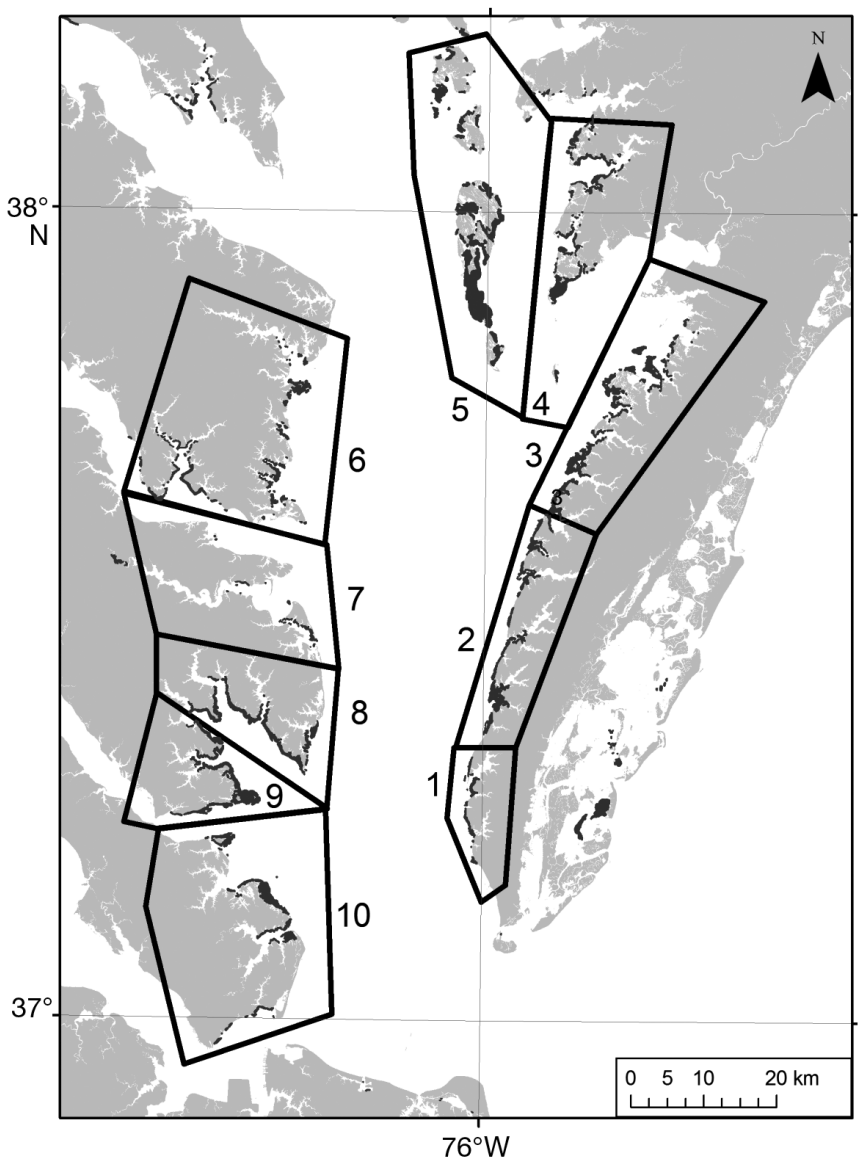

Fig. 1. Aerial extent of vegetated habitats (widgeon grass, eelgrass and macroalgae) in Chesapeake Bay in 2007 (dark gray patches). Black polygons represent distinct geographical regions separated by rivers and sandbars (modified from Harwell \& Orth 2002). The distribution of vegetated habitats in 2008 was very similar, though the total area was slightly higher (Orth et al. 2008). See Table 1 for area of each polygon. Gray shading: land; white: water

rather than equally across the shores. Approximately twice as many samples were taken on the eastern shore than the western shore, as nearly two-thirds of the seagrass beds in Chesapeake Bay are located along the eastern shore and in Tangier Sound. In 2007, 43 samples were taken, with 33 and 10 on the eastern and western shores, respectively; in 2008, 61 samples were taken, with 40 and 21 on the eastern and western shores, respectively (Fig. 2). Samples were taken over a period of $8 \mathrm{~d}$ in 2007 and $30 \mathrm{~d}$ in 2008.

At each randomly selected sampling location, a $1.68 \mathrm{~m}^{2}$ drop net was tossed off the boat as close as possible to the randomly generated GPS coordinates. The net was thrown from the bow of the boat while the engine was in neutral to minimize disturbance of the juvenile crabs at the sampling location. Although multiple components of habitat complexity, including
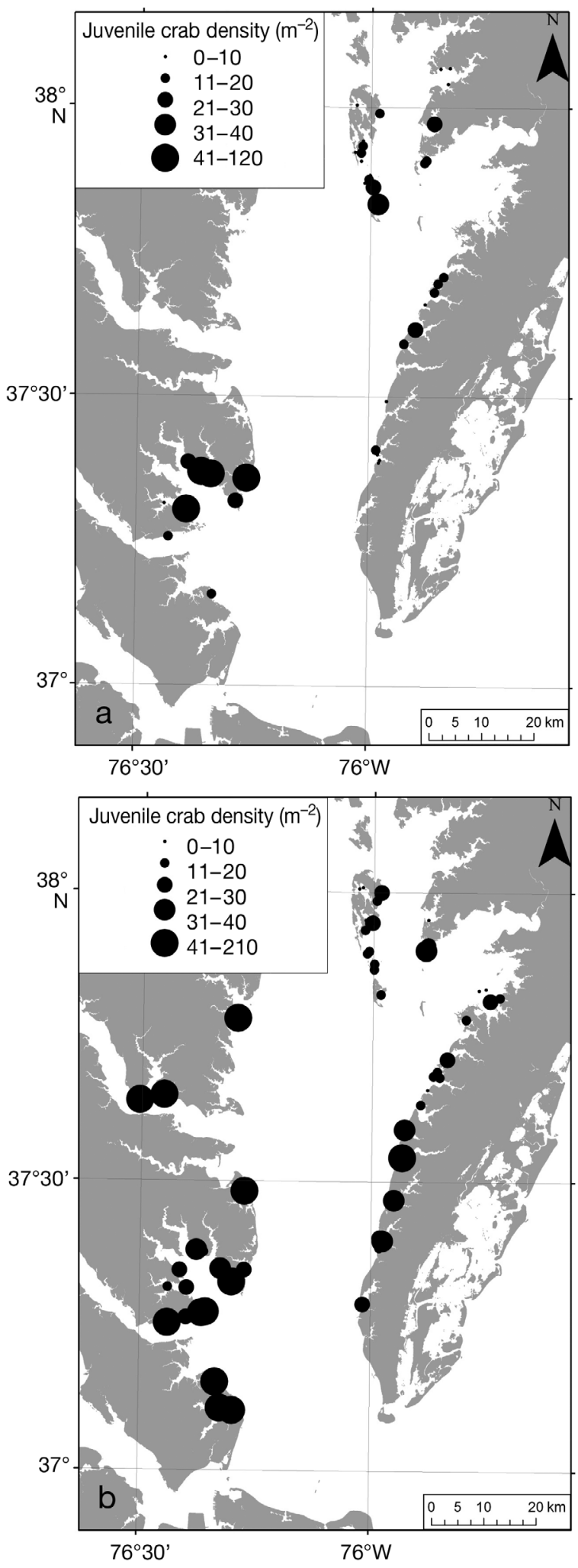

Fig. 2. Callinectes sapidus. Sampling locations and crab density ( $\leq 30 \mathrm{~mm}$ carapace width) for (a) 2007 and (b) 2008 . In total, 43 samples were taken in 2007, 33 on the eastern shore and 10 on the western shore. In 2008, 61 samples were taken, 40 on the eastern shore and 21 on the western shore 
shoot density, percent cover, and shoot height could potentially influence the density of juveniles, we decided to utilize percent cover within the net because it was the most consistent measurement and least likely to be influenced by observer bias (Dethier et al. 1993). Counting or measuring the length of each blade within a $1.68 \mathrm{~m}^{2}$ area would influence density estimates, and taking a small core (e.g. $0.018 \mathrm{~m}^{2}$, Hovel \& Lipcius 2001, 2002) was unlikely to represent the entire area within the net given the patchy nature of seagrass beds in the fall. Percent cover of vegetation (i.e. seagrass and associated macroalgae) was visually estimated to the nearest $5 \%$ increment. Although the amount of macroalgae varied, it was rarely a dominant component, but was included in the estimates due to its prevalence and because it would increase habitat complexity within the sample. Of the 104 samples, macroalgae was present in 15 , and comprised $>15 \%$ of the total cover in only 6 samples. A suction sampler, modified from Orth \& van Montfrans (1987), was used to collect blue crabs to a sediment depth of about 5 to $10 \mathrm{~mm}$. This method samples blue crabs with $80 \%$ efficiency in seagrass (R. Lipcius, unpubl. data), but leaves most of the shoots intact. Each sample was pumped through a $1 \mathrm{~mm}$ mesh collecting bag, then returned to the laboratory, and frozen before processing. Each sample was sorted twice for quality assurance, and the blue crabs were counted, sexed, and measured for carapace width with Vernier calipers, then preserved in $70 \%$ ethanol. Only crabs $\leq 30 \mathrm{~mm} \mathrm{CW}$ were included in the analysis, as this represents the size range of recruited juveniles in seagrass (Orth \& van Montfrans 1987, Pile et al. 1996, Lipcius et al. 2007); there were relatively few crabs $>30 \mathrm{~mm}$ CW in the samples.

To evaluate landscape-level effects on juvenile density, 2 additional variables were calculated in ArcGIS 10.1. Nominal measures of seagrass bed area were calculated from the annual seagrass survey (Orth et al. 2008, 2009, 2010) for the spring before the sampling season and for the spring after (e.g. for samples taken in 2007, we used the 2007 and 2008 spring aerial surveys). The distance from each sample to the mouth of Chesapeake Bay via the deepest channels was also calculated, where the deepest channels were delineated from a National Oceanic and Atmospheric Administration (NOAA), National Ocean Service (NOS) $30 \mathrm{~m}$ gridded digital elevation model. ${ }^{\mathbf{1}}$

1NOAA/NOS (2006) Thirty meter gridded DEM for Chesapeake Bay bathymetry. Created by Robert Conkwright, using ESRI ArcInfo 9.1; http://estuarinebathymetry.noaa.gov/ bathy_htmls/M130.html

\section{Statistical analyses and hypotheses}

To address the shape of the relationship between vegetation cover and juvenile crab density, we assessed whether the data met the assumptions of the linear model. Three other plausible models, hyperbolic, exponential, and sigmoid, were considered during analysis of the data. While additions of vegetation at low levels of cover may lead to rapid increases in crab density (i.e. a hyperbolic function), high-density vegetation may provide additional resources and refuge that can support much higher densities of juveniles (i.e. an exponential function). However, newly settled blue crabs exhibit densitydependent emigration from vegetated habitats (Blackmon \& Eggleston 2001, Etherington et al. 2003, Reyns \& Eggleston 2004), suggesting an upper limit to the number of juveniles within a given area (i.e. a sigmoid function).

Seagrass bed area and location may also influence crab density. The eastern and western shores of the Chesapeake Bay exhibit 2 distinct morphologies: the western shore is primarily composed of large tributaries, whereas the eastern shore is dominated by small creeks and shallow sand bars. These differences and the greater area of seagrass on the eastern shore were expected to result in lower densities of juveniles on the eastern shore, where there are fewer impediments to migration. A positive relationship was also expected between bed area (Table 1) and juvenile density, as larger beds produce stronger chemical cues to which immigrating postlarvae or young juveniles may respond (Welch et al. 1997) and they have lower

Table 1. Area of vegetated habitat $\left(\mathrm{km}^{2}\right)$ within each region (1 to 10, see Fig. 1). Distinct geographic regions are separated by rivers and sandbars (modified from Harwell \& Orth 2002). Aerial extent of vegetated habitat was modified from the Virginia Institute of Marine Science annual survey (Orth et al. 2008, 2009, 2010)

\begin{tabular}{|crrr|}
\hline Region & 2007 & 2008 & 2009 \\
\hline 1 & 1.8 & 2.1 & 2.4 \\
2 & 9.0 & 10.4 & 11.8 \\
3 & 14.4 & 18.1 & 22.9 \\
4 & 9.3 & 11.2 & 14.8 \\
5 & 32.8 & 37.4 & 42.4 \\
6 & 8.6 & 12.1 & 15.2 \\
7 & 0.9 & 1.3 & 3.5 \\
8 & 9.5 & 12.3 & 12.7 \\
9 & 10.5 & 12.4 & 13.4 \\
10 & 8.9 & 12.1 & 14.9 \\
Total & 105.7 & 129.4 & 154.1 \\
\hline
\end{tabular}


edge-to-interior ratios, which could limit emigration (Eggleston et al. 1998). As blue crab megalopae reinvade the bay from the coastal ocean, a negative relationship was expected between juvenile density and distance from the bay mouth. The presence of algae was expected to increase juvenile crab density, as it could provide additional structure and refuge.

We used Akaike's information criterion (AIC) within an information theoretic framework (Burnham \& Anderson 2002, Anderson 2008) to evaluate which environmental variables were important in predicting juvenile blue crab density. This method relies on the development of multiple working hypotheses with associated mathematical models. The Kendall rank correlation coefficient $(\tau)$ was used to determine colinearity between the covariates, including juvenile density, percent cover of seagrass, bed area, and distance to the bay mouth. We proposed a total of 11 models comprised of the main effects and the interaction between shore and percent cover of vegetation (Table 2). All statistical analyses were run in the open-source statistical software package R (R Development Core Team 2008).

The benefit of using AIC compared with other more traditional statistical methods is its ability to compare hypotheses against each other, through the likelihood of each model. To correct for a potential bias due to small sample sizes, the corrected AIC (AICc) was used (Anderson 2008). Each model was assessed by calculations that result in a weight $\left(w_{i}\right)-$ the probability that model $i$ is the best model out of the candidate set of models (Anderson 2008):

$$
\mathrm{AICc}=-2 \log (\widehat{L})+2 k+\frac{2 k(k+1)}{n-k-1}
$$

where $n$ is the number of samples, $k$ is the number of parameters, and $\hat{L}$ is the maximized values of the likelihood function for the estimated model;

and

$$
\Delta_{i}=\mathrm{AICC}_{i}-\min \left(\mathrm{AICC}_{i}\right)
$$

$$
w_{i}=\frac{\mathrm{e}^{-0.5 \Delta_{i}}}{\sum \mathrm{e}^{-0.5 \Delta_{i}}}
$$

One caveat to the study is that sampling could not be synoptic due to logistical constraints. The survey was completed in October and November, but recruitment can occur episodically through November in the Chesapeake Bay (van Montfrans et al. 1990). Thus, there was some unknown variability in the samples that confounds year and month effects. However, given that the majority of pulses have generally occurred in the 2 months immediately before our sampling (van Montfrans et al. 1995), we are confident that our sampling represents a reasonable estimate of juvenile density in these habitats.

\section{RESULTS}

In 2007, the percent cover of vegetation ranged from 5 to $100 \%$, with 6 of the 43 samples having $<20 \%$ cover; in 2008, percent cover ranged from 20 to $100 \%$. Percent cover within the samples was not

Table 2. Models used in the Akaike's information criterion analysis of blue crab density. $k=$ the number of parameters in each model. Cover refers to the percent of the sample ring that was covered with seagrass. $x_{2}=0$ for eastern shore and 1 for western shore. Bed Area refers to the area of the seagrass bed within which each sample was taken (i.e. patch size), based on the aerial seagrass survey from May to June of the year after the sample was taken. Distance refers to the distance to the bay mouth

\begin{tabular}{|c|c|c|c|c|c|c|c|c|}
\hline \multirow{2}{*}{ Model } & \multirow{2}{*}{$k$} & & & & \multirow{2}{*}{$\begin{array}{c}\text { - Variables } \\
x_{3} \\
\text { Bed Area }\end{array}$} & \multirow[b]{2}{*}{$\begin{array}{c}x_{4} \\
\text { Distance }\end{array}$} & \multirow[b]{2}{*}{$\begin{array}{c}x_{5} \\
\text { Algae }\end{array}$} & \multirow[b]{2}{*}{$\begin{array}{c}x_{1} \times x_{2} \\
\text { Cover } \times \text { Shore }\end{array}$} \\
\hline & & Intercept & $\begin{array}{c}x_{1} \\
\text { Cover }\end{array}$ & $\begin{array}{c}x_{2} \\
\text { Shore }\end{array}$ & & & & \\
\hline$g_{1}$ & 3 & $\beta_{0}$ & $\beta_{1}$ & & & & & \\
\hline$g_{2}$ & 3 & $\beta_{0}$ & & $\beta_{2}$ & & & & \\
\hline$g_{3}$ & 3 & $\beta_{0}$ & & & $\beta_{3}$ & & & \\
\hline$g_{4}$ & 3 & $\beta_{0}$ & & & & $\beta_{4}$ & & \\
\hline$g_{5}$ & 3 & $\beta_{0}$ & & & & & $\beta_{5}$ & \\
\hline$g_{6}$ & 4 & $\beta_{0}$ & $\beta_{1}$ & $\beta_{2}$ & & & & \\
\hline$g_{7}$ & 5 & $\beta_{0}$ & $\beta_{1}$ & $\beta_{2}$ & $\beta_{3}$ & & & \\
\hline$g_{8}$ & 5 & $\beta_{0}$ & $\beta_{1}$ & $\beta_{2}$ & & $\beta_{4}$ & & \\
\hline $\mathrm{g}_{9}$ & 5 & $\beta_{0}$ & $\beta_{1}$ & $\beta_{2}$ & & & $\beta_{5}$ & \\
\hline$g_{10}$ & 5 & $\beta_{0}$ & $\beta_{1}$ & $\beta_{2}$ & & & & $\beta_{6}$ \\
\hline$g_{11}$ & 7 & $\beta_{0}$ & $\beta_{1}$ & $\beta_{2}$ & $\beta_{3}$ & $\beta_{4}$ & $\beta_{5}$ & \\
\hline
\end{tabular}
along the deepest channels. $x_{5}=1$ if any algae was present in the sample and 0 if algae was absent. If a $\beta$ is located in a column then that variable was included in the model. All models were run using the exponential transformation, $\ln (y)$ 


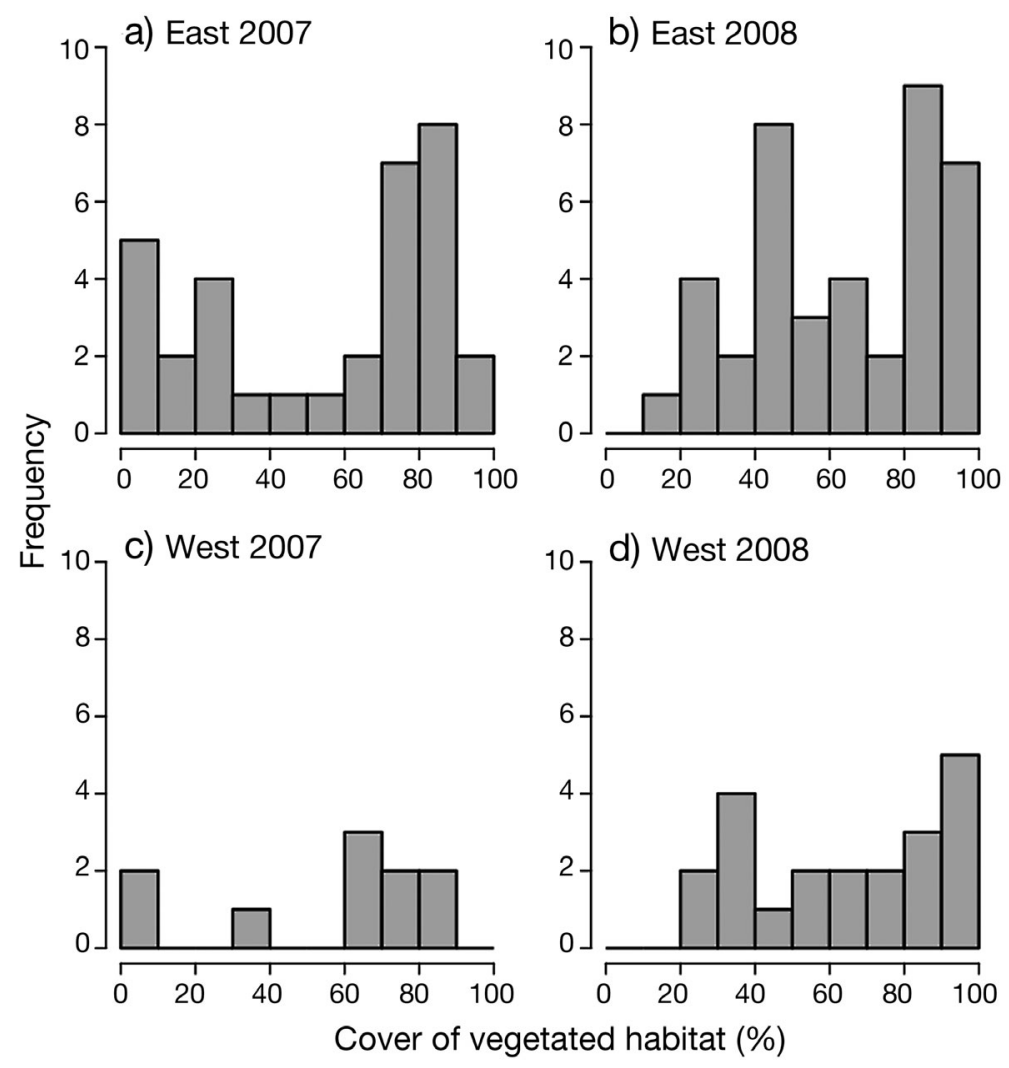

Fig. 3. Frequency histograms for the percent cover of vegetated habitats (widgeon grass, eelgrass and macroalgae) within each sample according to year $(2007,2008)$ and shore (east, west). In 2008, samples were not taken if the vegetation cover was $<20 \%$ : 1 sample that had

$20 \%$ cover (in Panel B) is depicted in the 10 to $20 \%$ cover bar

Table 3. Two-way ANOVA results for the percent vegetation cover in Chesapeake Bay, Virginia, by year (2007 and 2008) and shore (eastern and western). Percent cover of vegetation estimates are from the visual inspections of the drop net at each sampling location

\begin{tabular}{|lcccc|}
\hline Source & df & MS & $F$ & $p$ \\
\hline Shore & 1 & 0.48 & 0.08 & 0.57 \\
Year & 1 & 7.93 & 1.38 & 0.02 \\
Shore $\times$ Year & 1 & 1.79 & 0.31 & 0.74 \\
Residuals & 94 & 5.75 & & \\
\hline
\end{tabular}

Table 4. Two-way ANOVA results for the size of blue crabs in Chesapeake Bay, Virginia, by year (2007 and 2008) and shore (eastern and western)

\begin{tabular}{|lcrrc|}
\hline Source & df & MS & \multicolumn{1}{c|}{$F$} & p \\
\hline Shore & 1 & 20.67 & 73.62 & $<<0.01$ \\
Year & 1 & 66.84 & 238.10 & $<<0.01$ \\
Shore $\times$ Year & 1 & 4.29 & 15.29 & $<<0.01$ \\
Residuals & 3348 & 0.28 & & \\
\hline
\end{tabular}

statistically different between eastern and western shores (Fig. 3, Table 3).

Crab size was log-normally distributed with an overall mean of $7.4 \mathrm{~mm} \mathrm{CW}(95 \% \mathrm{CI}$ : 6.6 to $8.2 \mathrm{~mm}$ ). Crabs were significantly smaller in 2008 than in 2007, and significantly smaller on the western shore than the eastern shore in both years. The difference between the mean size of juvenile crabs on the eastern and western shores was greater in 2007 than in 2008, and the Year $\times$ Shore interaction was significant (Fig. 4, Table 4).

Juvenile density was log-normally distributed with an overall mean of 24.0 crabs $\mathrm{m}^{-2}$ $(\mathrm{SE}=2.7)$. Mean density of juvenile blue crabs in 2007 was 16.9 crabs $\mathrm{m}^{-2}$ ( $\mathrm{SE}=3.1$ ); excluding the samples where seagrass cover was $<20 \%$ resulted in a density of 19.2 crabs $\mathrm{m}^{-2}$ (SE = 3.5). In 2008, the density was 29.0 crabs $\mathrm{m}^{-2}(\mathrm{SE}=3.9)$. Density of juveniles was significantly higher in 2008 than 2007 ( $t=$ 3.39, df = 58.7, $\mathrm{p}=0.001$ ).

The estimates of patch size from the year of the sampling and the year after were highly positively correlated in 2007 and 2008 ( $\tau$ > 0.75). The correlations for all other pairs of environmental factors were weak $(|\tau|<0.20)$. There was a small negative correlation between juvenile density and distance to the mouth of the bay ( $\tau=-0.22$ and -0.32 in 2007 and 2008, respectively).

The linear function for crab density vs. percent cover of seagrass did not fit the data well, as evidenced by non-random residuals and heterogeneous variance, and was removed from further analysis. A polynomial fit to the data (LOWESS, locally weighted scatterplot smoothing) did not exhibit a peaked or asymptotic distribution, and indicated that an exponential or sigmoid model would be most appropriate. Given that the exponential model had randomly distributed residuals, that it did not exhibit heterogeneity of variance, and that the data did not approach an asymptote, the exponential model was used for the following analyses.

Based on the AIC model comparisons, models that contained only one of the predictor variables (models $g_{1}$ to $g_{5}$ ) had virtually no support (i.e. $w_{i} \ll$ 0.001). The additive model of percent cover and shore, model $g_{6}$, received the highest weight in 2007, while the additive model of percent cover, shore, and distance to bay mouth, $9_{8}$, received the highest weight in 2008 (Table 5). However, including additional parameters, beyond percent cover 
a) East 2007

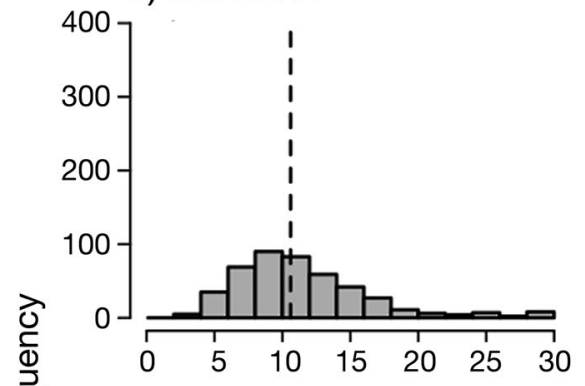

c) West 2007

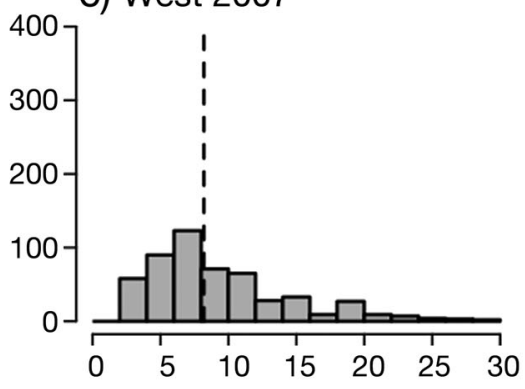

b) East 2008

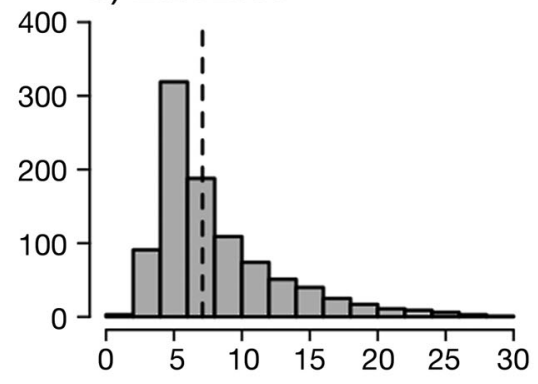

d) West 2008

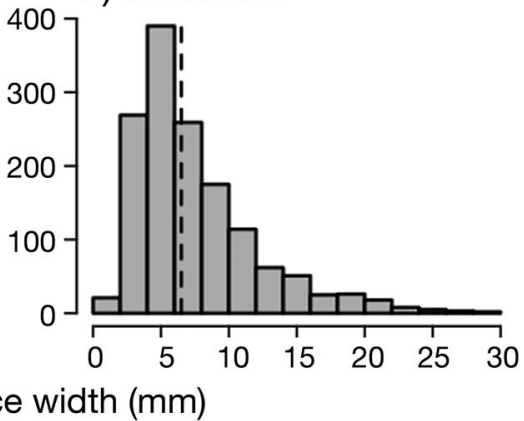

Fig. 4. Callinectes sapidus. Size-frequency histograms for juvenile blue crabs ( $\leq 30 \mathrm{~mm}$ carapace width) according to year $(2007,2008)$ and shore (east, west). The dashed vertical line is the back-transformed mean size for each year by shore combination based on the natural log transformation: (a) $10.6 \mathrm{~mm}$, (b) $7.1 \mathrm{~mm}$, (c) $8.2 \mathrm{~mm}$, and (d) $6.5 \mathrm{~mm}$

Table 5. Results of the Akaike's information criterion (AIC) analysis of blue crab density for 2007 and 2008. $k=$ the number of parameters in each model. The change in the corrected AIC $\left(\Delta_{\mathrm{AICC}}\right)$ and the weight of model $i\left(w_{i}\right)$ are calculated from the log-likelihood of each model. Adjusted $\mathrm{r}^{2}$ was used because it takes into account the number of parameters in the model. $n=43$ for 2007 and $n=61$ for 2008. All models were run using the exponential transformation, $\ln (y)$

\begin{tabular}{|c|c|c|c|c|c|c|c|}
\hline \multirow[t]{2}{*}{ Model } & \multirow[t]{2}{*}{$k$} & \multicolumn{3}{|c|}{2007} & \multicolumn{3}{|c|}{2008} \\
\hline & & Adjusted $\mathrm{r}^{2}$ & $\Delta_{\mathrm{AICc}}$ & $\mathrm{w}_{i}$ & Adjusted $\mathrm{r}^{2}$ & $\Delta_{\mathrm{AICc}}$ & $\mathrm{w}_{i}$ \\
\hline$g_{1}$ & 3 & 0.382 & 14.3 & $<0.001$ & 0.165 & 36.3 & $<0.01$ \\
\hline$g_{2}$ & 3 & 0.186 & 26.2 & $<0.001$ & 0.331 & 22.8 & $<0.01$ \\
\hline$g_{3}$ & 3 & -0.010 & 35.5 & $<0.001$ & 0.004 & 47.1 & $<0.01$ \\
\hline$g_{4}$ & 3 & -0.012 & 35.6 & $<0.001$ & 0.168 & 36.2 & $<0.01$ \\
\hline$g_{5}$ & 3 & 0.024 & 33.0 & $<0.001$ & -0.016 & 48.4 & $<0.01$ \\
\hline$g_{6}$ & 4 & 0.571 & 0.0 & 0.29 & 0.514 & 4.6 & 0.07 \\
\hline$g_{7}$ & 5 & 0.566 & 2.0 & 0.10 & 0.512 & 6.2 & 0.03 \\
\hline$g_{8}$ & 5 & 0.578 & 0.8 & 0.19 & 0.559 & 0.0 & 0.74 \\
\hline$g_{9}$ & 5 & 0.578 & 0.8 & 0.19 & 0.511 & 6.3 & 0.03 \\
\hline$g_{10}$ & 5 & 0.579 & 0.7 & 0.20 & 0.514 & 5.9 & 0.04 \\
\hline$g_{11}$ & 7 & 0.562 & 5.8 & 0.02 & 0.547 & 4.5 & 0.08 \\
\hline
\end{tabular}

and shore, added little in terms of goodness of fit, and in the supported models (i.e. with $w_{i}>0.1$ ) only the parameter estimates for percent cover of vegetation and shore were estimated reliably (Table 6). Therefore, the most plausible model was the addi- tive model of percent cover and shore $\left(g_{6 i}\right.$ Fig. 5). Specifically, juvenile density increased exponentially with percent cover, but the steepness of the increase varied spatially (by shore) and temporally (by year).

We generated effect sizes for percent cover and shore based on model $\mathrm{g}_{6}$. On average, there were 30 and $14 \%$ more crabs for every $10 \%$ increase in seagrass cover for 2007 and 2008, respectively. The addition of seagrass at the low range of percent cover had a relatively smaller effect on the total density than the addition of the same amount of cover at the high range, but the percent change was the same. The western shore had higher densities of juveniles than the eastern shore at equivalent percent cover, with 5.2 times more crabs on the western shore in 2007 and 2.8 times as many in 2008.

\section{DISCUSSION}

\section{Crab density vs. percent vegetation cover}

This study is the first to define the relationship between vegetation cover and density of juvenile blue crabs at a broad spatial scale (100s of $\mathrm{km})$ representative of the population. We found an exponential relationship between vegetation cover and juvenile density in Chesapeake Bay, rather than the expected sigmoid relationship. The relationship was not static; the shape of the curve varied both spatially (eastern vs. western shore) and temporally (by year), suggesting that the relationship is driven by differences in recruitment over space and time.

Previous studies have found higher density, survival, and growth of juvenile blue crabs in vegetated habitats relative to nearby unvegetated habitats (e.g. Heck \& Orth 1980, Thomas et al. 1990, Williams et al. 1990, Lipcius et al. 2005, Seitz et al. 2005; see Lipcius et al. 2007 for a review); similar work has expanded this view to 
Table 6. Parameter estimates from the transformed data for models with $w_{i}>0.01$ for 2007 and 2008

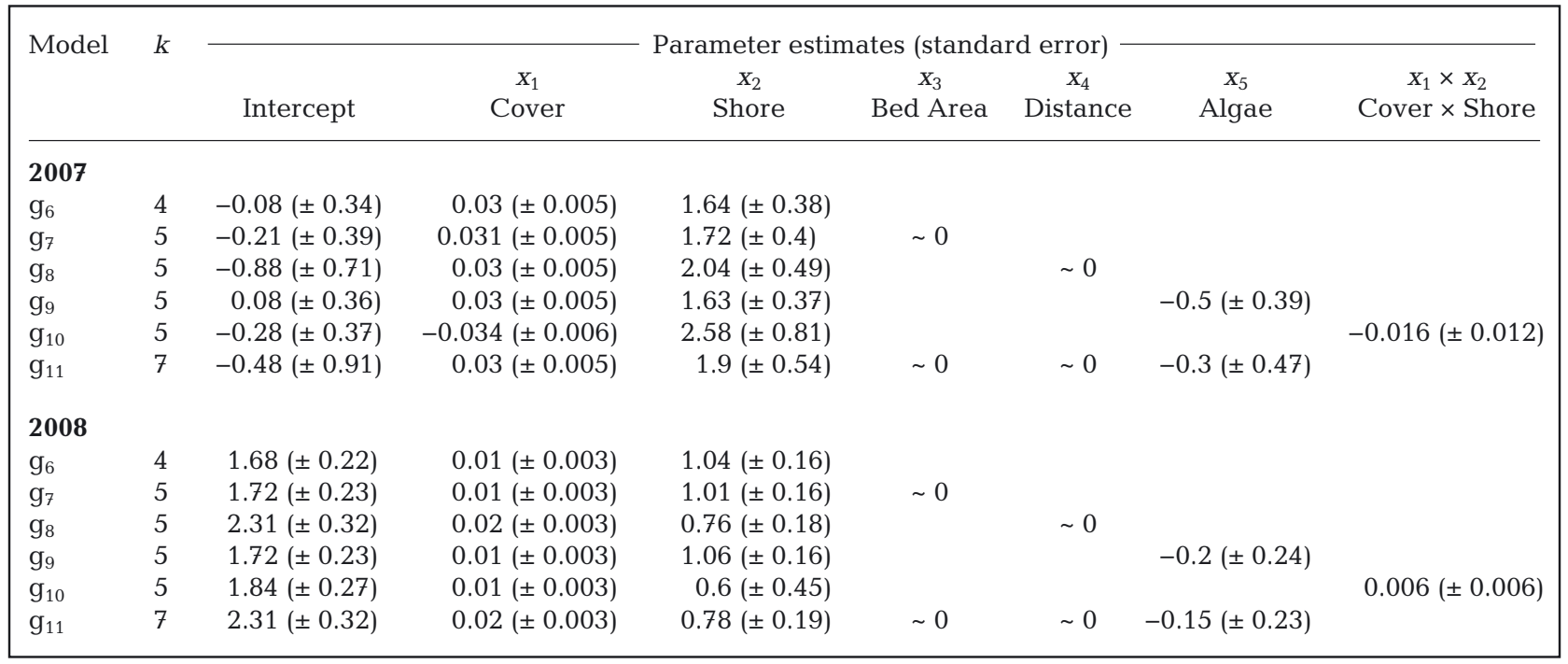

coarse woody debris (Everett \& Ruiz 1993). The few previous studies that assessed the shape of the relationship between juvenile blue crab variables (i.e. density or survival) and features of vegetated habitats were at small spatial scales. In a field experiment in the York River, Virginia, there were size-specific differences in the relationship between juvenile density and shoot density of small artificial eelgrass patches for juveniles of 3 size classes (Schulman
1996), though the relationship between juvenile density and shoot density was approximately sigmoid. Crab density was positively correlated with percent cover of seagrass (eelgrass, widgeon grass, and shoal grass Halodule wrightii) in field surveys of Core and Back Sounds, North Carolina, for juveniles 5 to $50 \mathrm{~mm} \mathrm{CW}$ (Hovel et al. 2002) and at the mouth of the York River, Virginia, for juveniles 10 to $30 \mathrm{~mm}$ CW (Hovel \& Lipcius 2001). a) 2007

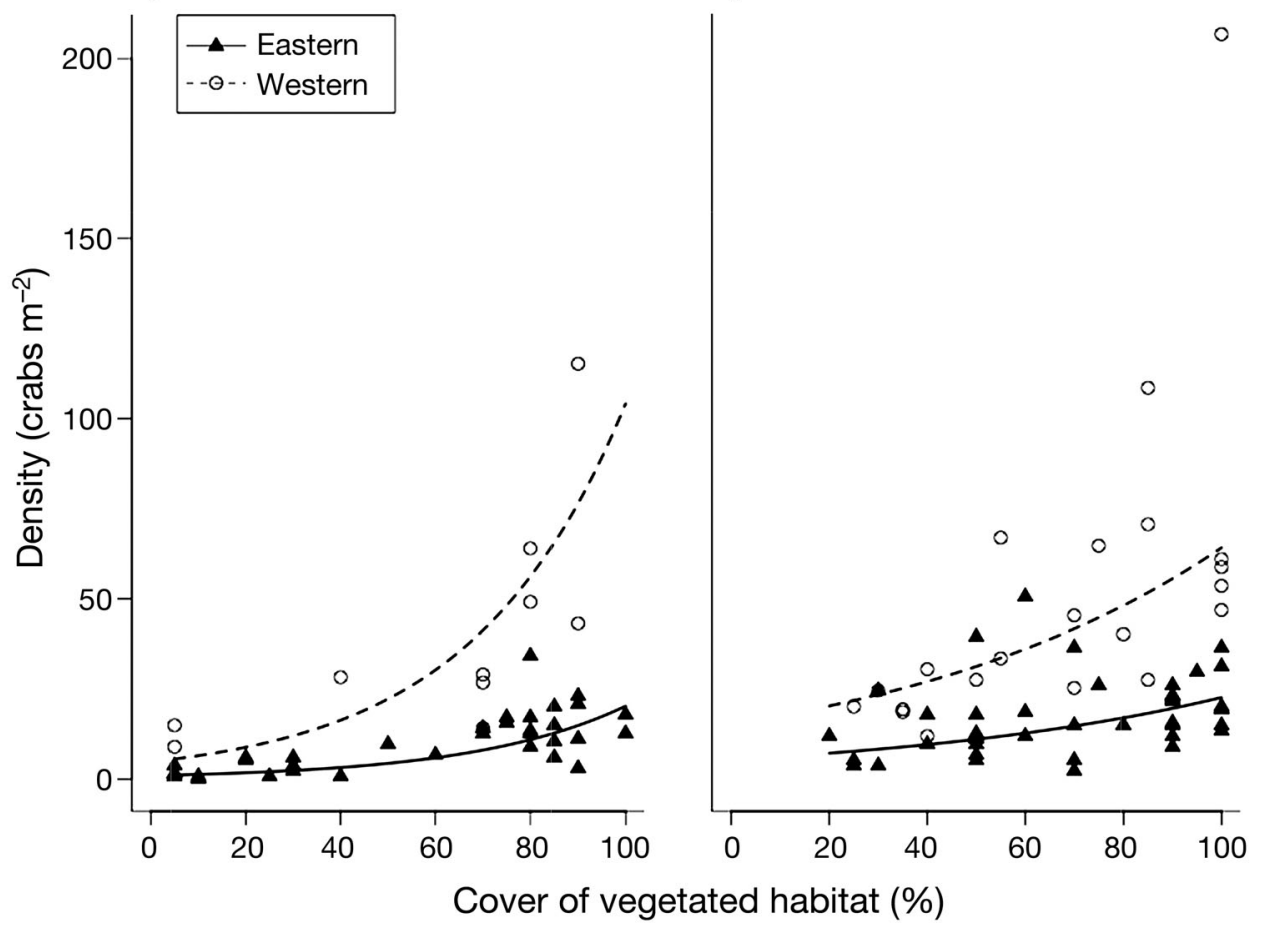

Fig. 5. Callinectes sapidus. Untransformed blue crab densities and model predictions for the best model as determined by the corrected Akaike's information criterion for (a) 2007 and (b) 2008. The predictions are based on the natural log transformation of the data 
This positive relationship may be a result of the ideal free distribution - the theory that individuals are distributed to match the available resources (Fretwell \& Lucas 1969). If juvenile blue crabs were distributed according to this theory, there should be higher densities of juveniles where resources are more abundant. For instance, foraging male blue crabs (130 to $170 \mathrm{~mm} \mathrm{CW}$ ) more than doubled their consumption rates when prey resources doubled (Clark et al. 2000), and growth of juvenile blue crabs (25 to $52 \mathrm{~mm} \mathrm{CW}$ ) was highest in areas of the York River where clam densities were highest (Seitz et al. 2005). If structural complexity, such as vegetation cover, is a proxy for habitat quality, there should be a positive relationship between habitat complexity and juvenile density. Structurally complex habitats often have higher densities of prey items (Beck et al. 2001) and provide refuge from predation by visual predators for juvenile blue crabs (Heck \& Thoman 1984, Orth \& van Montfrans 2002, Lipcius et al. 2005).

Although we identified a positive relationship between habitat complexity and juvenile density at a broad spatial scale, it is important to differentiate between component and demographic effects (Stephens et al. 1999, Kramer et al. 2009). A component effect changes a single or multiple components of fitness (e.g. growth rate, survival) while a demographic effect changes the overall fitness and drives population growth rate (Stephens et al. 1999). A component effect can suggest that there is potential for a demographic effect, but it does not necessarily translate into a demographic effect (Stephens et al. 1999). Thus, while we demonstrated a component effect, further information is needed to determine whether habitat complexity directly affects the population growth rate.

\section{Spatial and temporal patterns}

The relationship between percent cover of vegetation and juvenile crab density varied quantitatively, both spatially (higher on the western shore than eastern shore) and temporally (higher in 2008 than 2007). Potential explanations for these differences include both physical and biological mechanisms.

\section{Recruitment}

One potential mechanism to explain spatial differences is variation in recruitment: i.e. more juveniles might be imported to the western shore of the Chesapeake Bay compared with the eastern shore. In the
York River, a tributary of the western shore of Chesapeake Bay, a coupled biological and hydrodynamic model suggested spatial differences in blue crab postlarval settlement (Stockhausen \& Lipcius 2003). At the mouth of the river, predicted settlement was higher on the northern shore than on the southern shore. Furthermore, the high predicted settlement at the mouth of the river created a settlement shadow upriver (Stockhausen \& Lipcius 2003). Although it is possible that the coupling between postlarval behavior and transport processes results in higher densities of juveniles on the western shore compared with the eastern shore, the evidence from circulation patterns is ambiguous. Advection into the estuary from the continental shelf occurs through wind-driven transport of surface waters (Epifanio 2007), and via highdensity bottom water delivered via net nontidal flow below the outflowing surface waters on the western shore, and throughout the water column on the eastern shore (Tyler \& Seliger 1978, Roman \& Boicourt 1999). Thus, there are physical mechanisms that could deliver postlarvae earlier to the western shore than the eastern shore, but these are neither consistent nor conclusive.

Interannual differences in recruitment could also explain higher densities of juveniles in 2008 compared with 2007. Consistent with this hypothesis, the bay-wide density of Age 0 crabs (i.e. juveniles $<60 \mathrm{~mm}$ in CW) was 11.6 crabs $1000 \mathrm{~m}^{-2}$ (95\% confidence interval: 9.5 to 13.6 crabs $1000 \mathrm{~m}^{-2}$ ) in 2007 and 17.6 crabs $1000 \mathrm{~m}^{-2}$ (95\% confidence interval: 14.5 to 19.9 crabs $1000 \mathrm{~m}^{-2}$ ) in 2008 (Miller et al. 2011), suggesting blue crab recruitment was higher in 2008 .

Habitat

The overall amount of seagrass available for settlement could contribute to the estimates of juvenile density. If postlarvae were approximately equally distributed around the lower bay, but the area of vegetated habitats into which the postlarvae could settle varied spatially, the densities of juveniles could also vary spatially. For example, if there were twice as much seagrass on the eastern shore than on the western shore, an equal number of juveniles recruiting to both shores would result in densities on the eastern shore being half that of the western shore. The amount of seagrass estimated from aerial monitoring in the late spring during this sampling on the eastern shore was higher than that on the western shore in May and June (Orth et al. 2008, 2009), potentially be- 
cause of a broader distribution across a greater depth range on the eastern shore than on the western shore (Orth \& Moore 1988).

The spatial extent of seagrass could also explain differences by year. In the lower bay, the area of seagrass increased $24 \%$ from 10650 ha in early summer of 2007 to 13225 ha in early summer of 2008 (Orth et al. 2008). This would suggest that, given constant recruitment, densities would decrease between 2007 and 2008. Instead, there was a $51 \%$ increase in juvenile crab density in seagrass, agreeing well with a $52 \%$ increase in recruitment as determined by the density of Age 0+ crabs in the bay-wide winter dredge survey (Miller et al. 2011). However, the 2 dominant seagrass species in Chesapeake Bay (eelgrass and widgeon grass) undergo spatially and temporally variable annual defoliation during the late summer and early fall — before our juvenile blue crab sampling. As there is no quantitative measure of the extent of seagrass during peak recruitment, this mechanism cannot be rigorously evaluated at present.

\section{Growth and emigration}

Juvenile blue crabs exhibit an ontogenetic shift in habitat use from seagrass to unvegetated habitats after $\sim 20$ to $30 \mathrm{~mm}$ CW (Orth \& van Montfrans 1987, Hines 2007, Lipcius et al. 2007, Johnston \& Lipcius 2012). Spatial variability in growth rates could result in juveniles moving out of seagrass beds faster in one region than another. Such a pattern of spatial variability in growth has been observed in other species. For example, spotted seatrout Cynoscion nebulosus growth differed between the eastern and western shores of Chesapeake Bay and in wet and dry years (Smith et al. 2008). Under normal flow conditions, growth was higher on the eastern shore than on the western shore; under drought conditions, this trend was reversed (Smith et al. 2008). Previous studies found spatial differences in juvenile blue crab growth. Small juvenile blue crabs (mean $\mathrm{CW}=2.65 \mathrm{~mm}$ ) grew faster in seagrass compared with unvegetated habitats in both field and laboratory experiments (Perkins-Visser et al. 1996). Larger juveniles (25 to $52 \mathrm{~mm}$ CW) grew at similar rates in downriver vegetated habitats and upriver unvegetated habitats (Seitz et al. 2005). If juveniles grow faster on the eastern shore compared with the western shore, juveniles from a single recruitment pulse would leave vegetated habitats earlier on the eastern shore than on the western shore, and potentially contribute to the lower densities found on the eastern shore. This scenario agrees with our demonstrated larger average juvenile crab size on the eastern shore than the western shore.

The differences in sampling dates could also have contributed to the significantly smaller sizes and higher densities of juveniles collected on the western shore compared with those on the eastern shore. In 2007, samples from the eastern shore were taken 4 to $8 \mathrm{~d}$ later than those from the western shore. The delay in sampling the eastern shore could have allowed the juveniles more time to grow, and die or emigrate from vegetated habitats, resulting in fewer, larger juveniles on the eastern shore. Newly settled juveniles grew an average of 1.5 to $2.1 \mathrm{~mm} \mathrm{CW}$ week $^{-1}$ in field enclosures (Perkins-Visser et al. 1996), which is close to the difference in size between the eastern and western shores in 2007. However, it is difficult to extrapolate those results to a more natural setting and larger crabs. Similar trends in density and size were observed in 2008. The samples were taken over a larger spatial and temporal extent in 2008, but again, most samples were taken earlier on the western shore than on the eastern shore.

\section{Landscape effects}

Previous studies have shown that juvenile blue crab survival can be influenced by landscape-level factors, such as patch size (Hovel \& Fonseca 2005, but see Hovel \& Lipcius 2001) and fragmentation type (Hovel \& Lipcius 2002). The relationship between juvenile density and seagrass bed area may have been masked by a bias in the estimates of bed area from the aerial survey. These estimates may not reflect the actual habitat encountered by the postlarvae and young juveniles in late summer and fall, as seagrasses in Chesapeake Bay undergo an annual defoliation in late summer. Conversely, postlarvae and young juveniles may not be responding to seagrass bed area at the scale measured by the aerial survey, and localized patchiness may be more important in controlling juvenile density.

Given the movement of postlarvae into Chesapeake Bay from the coastal ocean, the weak statistical relationship between distance to the bay mouth and juvenile density was surprising. The use of distance via deep channels may be biased, as currents and tides, strong drivers of postlarval recruitment, are not incorporated in this measure. Perhaps a better measure of distance could explicitly include hydrodynamic drivers of postlarval and juvenile advection. 


\section{Climate change and the future of vegetated habitat in Chesapeake Bay}

Climate change will play a complex role in the life cycle of the blue crab, especially as it relates to the distribution and abundance of vegetated habitat. Abundance of the temperate species, eelgrass, is likely to continue to decline given the expected increases in water temperature and phytoplankton abundance, whereas the other abundant estuarine seagrass in Chesapeake Bay, widgeon grass, is more tolerant of higher water temperatures and may be more resistant or resilient to these changes (Evans et al. 1986). Other studies suggest that juvenile blue crabs can have similar survival and growth in emerging ecosystems such as Gracilaria spp., a complex red macroalga (Falls 2008, Johnston \& Lipcius 2012). Juvenile blue crab densities in Gracilaria spp. patches in Rehoboth Bay (Epifanio et al. 2003) and in Chesapeake Bay were similar to those in seagrass patches. Larval abundance and postlarval recruitment decreased by an order of magnitude between 1992 and 2000 compared with earlier years (Lipcius \& Stockhausen 2002). Seagrass in Chesapeake Bay was recovering through the mid-1990s, after which another prolonged decline began (Orth et al. 2010). While this period of relatively high seagrass abundance and high juvenile abundance, followed by a period of low seagrass and low juvenile abundance, suggests that there might be a relationship between seagrass cover and crab density at the population level, other factors are probably at play. For example, the blue crab population was classified as overfished, with overfishing occurring for most of the decade leading up to this study; after reductions in fishing pressure in 2008, there have been recent increases in the total population. Given the continued ability of juveniles to utilize alternative vegetated habitats, it is unknown what effect further declines of eelgrass in the Chesapeake Bay will have on the blue crab population as well as the availability of alternative habitats.

\section{Caveats and recommendations}

This study was undertaken during a period of historically low blue crab recruitment and should be repeated during a period of high recruitment to test the generality of the findings. The lack of a threshold response of juvenile crabs to vegetation cover could have been caused by low densities of juveniles overall. Perhaps the exponential response would become a threshold response under higher recruitment. Recently, abundances of adult female and juvenile blue crabs have increased (Miller et al. 2011) in waters $>1.5 \mathrm{~m}$, but blue crab sampling in shallow waters is lacking. Continuing to sample juveniles in shallow, vegetated habitats is critical and would provide more information about the relationship between juvenile density and vegetation under different climate scenarios. Finally, the potential of the component effect of vegetation cover on juvenile blue crab density to be a demographic effect demands assessment either through further bay-wide population and vegetation sampling or by population modeling.

Acknowledgements. We thank the students and staff of the Marine Conservation Biology and Community Ecology labs at VIMS, especially the dedication of M. Seebo and J. van Montfrans. We also thank D. Wilcox and the VIMS Submerged Aquatic Vegetation laboratory for the use of the annual aerial surveys of seagrass and for generating the random sampling sites. We also thank M. Fabrizio and 3 anonymous referees for thoughtful comments on an earlier draft of this manuscript. G.M.R. gratefully acknowledges the support of the Willard A. Van Engel (WAVE) Fellowship in blue crab ecology and conservation. This study was supported by a grant to R.N.L., R.S.D., and R.J.O. from Virginia Sea Grant (NOAA) and partnered by the NOAA Chesapeake Bay Office through the Blue Crab Advanced Research Consortium. This paper is Contribution No. 3278 of the Virginia Institute of Marine Science, College of William and Mary.

\section{LITERATURE CITED}

Anderson DR (2008) Model based inference in the life sciences: a primer on evidence. Springer-Verlag, New York, NY

> Beck MW, Heck KL Jr, Able KW, Childers DL and others (2001) The identification, conservation, and management of estuarine and marine nurseries for fish and invertebrates. BioScience 51:633-641

> Blackmon DC, Eggleston DB (2001) Factors influencing planktonic, post-settlement dispersal of early juvenile blue crabs. J Exp Mar Biol Ecol 257:183-203

Burnham KP, Anderson DR (2002) Model selection and multimodel inference: a practical information-theoretic approach, 2nd edn. Springer-Verlag, New York, NY

> Clark ME, Wolcott TG, Wolcott DL, Hines AH (2000) Foraging behavior of an estuarine predator, the blue crab Callinectes sapidus in a patchy environment. Ecography 23:21-31

> Dethier MN, Graham ES, Cohen S, Tear LM (1993) Visual versus random-point percent cover estimations: 'objective' is not always better. Mar Ecol Prog Ser 96:93-100

Eggleston DB, Etherington LL, Elis WE (1998) Organism response to habitat patchiness: species and habitatdependent recruitment of decapod crustaceans. J Exp Mar Biol Ecol 223:111-132

Epifanio CE (2007) Biology of larvae. In: Kennedy VS, Cronin LE (eds) The blue crab Callinectes sapidus. Mary- 
land Sea Grant College, College Park, MD, p 513-533

Epifanio CE, Dittel AI, Rodriguez RA (2003) The role of macroalgal beds as nursery habitat for juvenile blue crabs, Callinectes sapidus. J Shellfish Res 22:881-886

Etherington LL, Eggleston DB, Stockhausen WT (2003) Partitioning loss rates of early juvenile blue crabs from seagrass habitats into mortality and emigration. Bull Mar Sci 72:371-391

Evans LA, Webb KL, Penhale PA (1986) Photosynthetic temperature acclimation in 2 co-existing seagrasses, Zostera marina L. and Ruppia maritima. Aquat Bot 24:185-197

Everett RA, Ruiz GM (1993) Coarse woody debris as a refuge from predation in aquatic communities. Oecologia 93:475-486

Falls JA (2008) The survival benefit of benthic macroalgae Gracilaria vermiculophylla as an alternative nursery habitat for juvenile blue crabs. MS thesis, Virginia Institute of Marine Science, College of William and Mary, Gloucester Point, VA

$>$ Fretwell SD, Lucas HL Jr (1969) On territorial behaviour and other factors influencing habitat distribution in birds. I. Theoretical development. Acta Biotheor 19:16-36

> Harwell MC, Orth RJ (2002) Seed bank patterns in Chesapeake Bay eelgrass (Zostera marina L.): a bay-wide perspective. Estuaries 25:1196-1204

> Heck KL Jr, Orth RJ (1980) Structural components of eelgrass (Zostera marina) meadows in the lower Chesapeake Bay - decapod crustacea. Estuaries 3:289-295

- Heck KL Jr, Thoman TA (1984) The nursery role of seagrass meadows in the upper and lower reaches of the Chesapeake Bay. Estuaries 7:70-92

Heck KL Jr, Hays G, Orth RJ (2003) Critical evaluation of the nursery role hypothesis for seagrass meadows. Mar Ecol Prog Ser 253:123-136

Hines AH (2007) Ecology of juvenile and adult blue crabs. In: Kennedy VS, Cronin LE (eds) The blue crab Callinectes sapidus. Maryland Sea Grant College, College Park, MD, p 565-654

Hovel KA, Fonseca MS (2005) Influence of seagrass landscape structure on the juvenile blue crab habitat-survival function. Mar Ecol Prog Ser 300:179-191

Hovel KA, Lipcius RN (2001) Habitat fragmentation in a seagrass landscape: patch size and complexity control blue crab survival. Ecology 82:1814-1829

Hovel KA, Lipcius RN (2002) Effects of seagrass habitat fragmentation on juvenile blue crab survival and abundance. J Exp Mar Biol Ecol 271:75-98

Hovel KA, Fonseca MS, Myer DL, Kenworthy WJ, Whitfield PE (2002) Effects of seagrass landscape structure, structural complexity and hydrodynamic regime on macrofaunal densities in North Carolina seagrass beds. Mar Ecol Prog Ser 243:11-24

ICES (International Council for the Exploration of the Sea) (2012) Report of the workshop on the value of coastal habitats for exploited species, Copenhagen, 25-29 June 2012, ICES CM 2012/SSGSUE:05

> Johnston CA, Lipcius RN (2012) Exotic macroalga Gracilaria vermiculophylla provides superior nursery habitat for native blue crab in Chesapeake Bay. Mar Ecol Prog Ser 467:137-146

Kramer AM, Dennis B, Liebhold AM, Drake JM (2009) The evidence for Allee effects. Popul Ecol 51:341-354

> Lipcius RN, Stockhausen WT (2002) Concurrent decline of the spawning stock, recruitment, larval abundance, and size of the blue crab Callinectes sapidus in Chesapeake
Bay. Mar Ecol Prog Ser 226:45-61

> Lipcius RN, Seitz RD, Seebo MS, Colon-Carrion D (2005) Density, abundance, and survival of the blue crab in seagrass and unstructured salt marsh nurseries of Chesapeake Bay. J Exp Mar Biol Ecol 319:69-80

Lipcius RN, Eggleston DB, Heck KL Jr, Seitz RD, van Montfrans J (2007) Post-settlement abundance, survival, and growth of postlarvae and young juveniles in nursery habitat. In: Kennedy VS, Cronin LE (eds) The blue crab Callinectes sapidus. Maryland Sea Grant College, College Park, MD, p 535-564

Miller TJ, Wilberg MJ, Colton AR, Davis GR and others (2011) Stock assessment of blue crab in Chesapeake Bay 2011. Tech Rep TS 614 11, University of Maryland Center for Environmental Science, Chesapeake Biological Laboratory, Solomons, MD

> Minello TJ, Able KW, Weinstein MP, Hays CG (2003) Salt marshes as nurseries for nekton: testing hypotheses on density, growth, and survival through meta-analysis. Mar Ecol Prog Ser 246:39-59

Orth RJ, Moore KA (1983) An unprecedented decline in submerged aquatic vegetation. Science 222:51-53

> Orth RJ, Moore KA (1988) Distribution of Zostera marina L. and Ruppia maritima L. sensu lato along depth gradients in the lower Chesapeake Bay, USA. Aquat Bot 32: 291-305

> Orth RJ, van Montfrans J (1987) Utilization of a seagrass meadow and tidal marsh creek by blue crabs (Callinectes sapidus). I. Seasonal and annual variations in abundance with emphasis on post-settlement juveniles. Mar Ecol Prog Ser 41:283-294

Orth RJ, van Montfrans J (1990) Utilization of marsh and seagrass habitats by early stages of Callinectes sapidus: a latitudinal perspective. Bull Mar Sci 46:126-144

Orth RJ, van Montfrans J (2002) Habitat quality and prey size as determinants of survival in post-larval and early juvenile instars of the blue crab Callinectes sapidus. Mar Ecol Prog Ser 231:205-213

Orth RJ, Wilcox DJ, Whiting JR, Nagey LS, Owens AL, Kenne AK (2008) 2007 distribution of submerged aquatic vegetation in Chesapeake Bay and coastal bays. Spec Sci Rep 151, Virginia Institute of Marine Science, College of William and Mary, Gloucester Point, VA, available at http://web.vims.edu/bio/sav/sav07/index.html

Orth RJ, Wilcox DJ, Whiting JR, Nagey LS, Owens AL, Kenne AK (2009) 2008 distribution of submerged aquatic vegetation in Chesapeake Bay and coastal bays. Spec Sci Rep 149, Virginia Institute of Marine Science, College of William and Mary, Gloucester Point, VA, available at http://web.vims.edu/bio/sav/sav08/index.html

Orth RJ, Marion SR, Moore KA, Wilcox DJ (2010) Eelgrass (Zostera marina L.) in the Chesapeake Bay region of mid-Atlantic coast of the USA: challenges in conservation and restoration. Estuaries Coasts 33:139-150

Orth RJ, Wilcox DJ, Whiting JR, Nagey LS, Owens AL, Kenne AK (2011) 2010 distribution of submerged aquatic vegetation in Chesapeake Bay and coastal bays. Spec Sci Rep 153, Virginia Institute of Marine Science, College of William and Mary, Gloucester Point, VA, available at http://web.vims.edu/bio/sav/sav10/index.html

> Perkins-Visser E, Wolcott TG, Wolcott DL (1996) Nursery role of seagrass beds: enhanced growth of juvenile blue crabs (Callinectes sapidus Rathbun). J Exp Mar Biol Ecol 198:155-173

Pile AJ, Lipcius RN, van Montfrans J, Orth RJ (1996) Den- 
sity-dependent settler-recruit-juvenile relationships in blue crabs. Ecol Monogr 66:277-300

R Development Core Team (2008) R: A language and environment for statistical computing. R Foundation for Statistical Computing, Vienna, available at www.Rproject.org

Reyns NB, Eggleston DB (2004) Environmentally-controlled, density-dependent secondary dispersal in a local estuarine crab population. Oecologia 140:280-288

Roman MR, Boicourt WC (1999) Dispersion and recruitment of crab larvae in the Chesapeake Bay plume: physical and biological controls. Estuaries 22:563-574

Schulman JL (1996) Habitat complexity as a determinant of juvenile blue crab survival. MS thesis, Virginia Institute of Marine Science, College of William \& Mary, Gloucester Point, VA

Seitz RD, Lipcius RN, Seebo MS (2005) Food availability and growth of the blue crab in seagrass and unvegetated nurseries of Chesapeake Bay. J Exp Mar Biol Ecol 319: $57-68$

Smith NG, Jones CM, van Montfrans J (2008) Spatial and temporal variability of juvenile spotted seatrout Cynoscion nebulosus growth in Chesapeake Bay. J Fish Biol 73:597-607

Stephens PA, Sutherland WJ, Freckleton RP (1999) What is the Allee effect? Oikos 87:185-190

Stockhausen WT, Lipcius RN (2003) Simulated effects of seagrass loss and restoration on settlement and recruitment of blue crab postlarvae and juveniles in the York River, Chesapeake Bay. Bull Mar Sci 72:409-422

Editorial responsibility: Richard Osman,

Edgewater, Maryland, USA
Thomas JL, Zimmerman RJ, Minello TJ (1990) Abundance patterns of juvenile blue crabs (Callinectes sapidus) in nursery habitats of two Texas bays. Bull Mar Sci 46: 115-125

Tyler MA, Seliger HH (1978) Annual subsurface transport of a red tide dinoflagellate to its bloom area: water circulation patterns and organism distributions in the Chesapeake Bay. Limnol Oceanogr 23:227-246

Van Engel WA (1958) The blue crab and its fishery in Chesapeake Bay. Commer Fish Rev 20:6-17

van Montfrans J, Peery C, Orth RJ (1990) Daily, monthly and annual settlement patterns by Callinectes sapidus and Neopanope sayi megalopae on artificial collectors deployed in the York River, Virginia: 1985-1988. Bull Mar Sci 46:214-229

van Montfrans J, Epifanio CE, Knott DM, Lipcius RN and others (1995) Settlement of blue crab megalopae in western North Atlantic estuaries. Bull Mar Sci 57: 834-854

> Welch JM, Rittschof D, Bullock TM, Forward RB Jr (1997) Effects of chemical cues on settlement behavior of blue crab Callinectes sapidus postlarvae. Mar Ecol Prog Ser 154:143-153

Williams AH, Coen LD, Stoelting MS (1990) Seasonal abundance, distribution, and habitat selection of juvenile Callinectes sapidus (Rathbun) in the northern Gulf of Mexico. J Exp Mar Biol Ecol 137:165-183

Wilson KA, Able KW, Heck KL Jr (1990) Habitat use by juvenile blue crabs: a comparison among habitats in southern New Jersey. Bull Mar Sci 46:105-114

Submitted: September 3, 2012; Accepted: May 21, 2013 Proofs received from author(s): July 31, 2013 